\title{
Oxymorphone Hydrochloride
}

National Cancer Institute

\section{Source}

National Cancer Institute. Oxymorphone Hydrochloride. NCI Thesaurus. Code C47648.

The hydrochloride salt form of oxymorphone, a semisynthetic opioid with a potent analgesic property. Oxymorphone hydrochloride binds to and activates opiate receptors, specifically mu-receptors, in the central nervous system (CNS). This results in sedation, analgesia, decreased gastrointestinal motility, and respiratory depression. 